\title{
KIAUŠIDĖS APSISUKIMAS: DIAGNOSTIKOS IŠŠŪKIAI. KLINIKINIS ATVEJIS
}

\author{
Paulius Burkauskas ${ }^{1}$, Karolina Baltrušaitytè ${ }^{1}$, Sonata Barilienè $\dot{\mathbf{2}}^{2}$ \\ ${ }^{1}$ Lietuvos sveikatos mokslu universiteto Medicinos fakultetas \\ ${ }^{2}$ Lietuvos sveikatos mokslu universiteto ligoninès Kauno kliniku Akušerijos ir ginekologijos klinika
}

Raktažodžiai: kiaušidès apsisukimas, pilvo skausmas.

\section{Santrauka}

Kiaušidès apsisukimas - tai patologija, kai dèl dažniausiai anatomiškai pakitusios kiaušidès apsisukimo aplink ją palaikančius raiščius ir (ar) kiaušintakị, nutrūksta šių organų kraujotaka ir išsivysto audinių nekrozè. Ne visada pavyksta laiku diagnozuoti ligą, o nediagnozuota ji gali komplikuotis vaisingumo praradimu, peritonitu ir netgi mirtimi. Diagnostikos tikslumas priklauso nuo ligoninès išteklių ir gydančiojo gydytojo patirties. Šiame straipsnyje pristatomas klinikinis atvejis, kai pacientei išsivystè kiaušidès apsisukimas, kurio dèl nespecifinių simptomų ir vaizdo tyrimų neinformatyvumo nepavyko laiku diagnozuoti. Skyrus adekvatų kiaušidès ir jos priklausinių apsisukimo gydymą, buvo stebima teigiama dinamika ir paciente išvyko iš stacionaro tęsti ambulatorini gydymą.

\section{Ivadas}

Kiaušidės apsisukimas - tai patologija, kai kiaušidė visiškai arba iš dalies apsisuka aplink pakabinamajị ir savajji kiaušidès raištị, kiaušintaki [1,2]. Sveikų gimdos priklausinių apsisukimas yra itin retas. Esant kiaušidès cistai, susidaro palankios sąlygos atsirasti šiai patologijai [3]. Tai 5 pagal dažnumą ginekologinè liga. Ja suserga 5,9/100000 moterų, bet tikrasis paplitimas nėra aiškus, kadangi tiksli diagnozè nustatoma tik operacijos metu [4]. Manoma, kad kiaušidès apsisukimas galimas iki 3 proc. pacienčių, kurios dèl ūmaus pilvo skausmo kreipiasi i skubiosios pagalbos skyrius $[1,2,5,6]$.

Darbo tikslas - supažindinti ịvairių specialybių gydytojus su kiaušidès apsisukimo diagnostikos ypatumais, pristatant klinikini atveji, pasitaikiusi Lietuvos sveikatos mokslų universiteto ligonineje (LSMUL).

\section{Klinikinis atvejis}

50 metų moteris kreipèsi į LSMUL skubiosios pagalbos skyriu dèl staiga atsiradusio stipraus pilvo skausmo kairèje klubinèje srityje, pykinimo bei vėmimo. Nusiskundimai iki kreipimosi truko 4 valandas. Skausmo stiprumas vaizdo analogijos skalejje (VAS) įvertintas 7 balais, plintantis ị kairiają koją. Apžiūrint nustatyta, kad paciente nekarščiuoja, ŠSD - 97 k/min, AKS 130/80 mmHg. Čiuopiant pilvas minkštas, skausmingas kaireje spina iliaca superior projekcijoje, skausmas plinta ị kairiają koją, pilvaplèvès dirginimo reiškinių nèra. Vaginaliai apžiūrint budinčiam gydytojui ginekologui vulva ir makštis be matomos patologijos, čiuopiant gimdos kaklelio simptomas neigiamas, gimda anteversis padètyje, normos dydžio. Palpuojant dešinèje gimdos priklausinių srityje jaučiamas neskausmingas 5-6 cm dydžio darinys. Kairès pusès apčiuopą sunkino skausmas (kiaušide nečiuopiama). Atliktuose kraujo tyrimuose nustatyta leukocitozè (WBC $\left.12.25 \times 10^{9} / 1\right)$ ir neutrofilija $(83,50 \%)$, biocheminiai kraujo tyrimai be pakitimų. Atlikus pilvo apžvalginę rentgenogramą, patologijos nerasta: laisvo oro po diafragma nenustatyta, žarnų spindžiai neišplèsti, skysčio-oro paviršiaus nematyti. Skubiai atliktame pilvo ultragarsiniame tyrime: dešinès kiaušidès projekcijoje cistinis darinys $\sim 6$ cm skersmens, pastebėta sustorẻjusi sienelè. Laisvo skysčio pilvaplèvès ermèje nematyti. Transvaginalinio ultragarsinio tyrimo metu (TVUG) matoma gimda anteversio padètyje, 100 x 60 x $67 \mathrm{~mm}$ dydžio, endometriumas $8 \mathrm{~mm}$, lygus. Užpakalineje gimdos sienoje matomas intramuralinis miomos mazgas 36 x 36 mm dydžio, dešinè kiaušide 73 x $54 \mathrm{~mm}$ su 54 x $44 \mathrm{~mm}$ vienkameriniu cistiniu dariniu be išaugų, kairioji kiaušidè ir kirmèlinė atauga nevizualizuojasi. Laisvo skysčio nėra. Daroma išvada, jog šiuo metu duomenų apie ūmią ginekologinę patologiją nepakanka. Dèl neaiškios skausmo priežasties paskirtas pilvo ir dubens organų KT tyrimas. Atliktame KT tyrime: parenchiminiai organai be pakitimų, tulžies pūslèje matomi keli iki $2,2 \mathrm{~cm}$ rentgeno- 
kontrastiniai konkrementai, sienelè nepakitusi. Gimdoje matomas 40 x $50 \mathrm{~mm}$ ị miomą panašus darinys. Dešinioji kiaušidè padidèjusi, jos projekcijoje matomas 56 x $53 \mathrm{~mm}$ dydžio plonasienis cistinis darinys, greta jo keli analogiškos struktūros iki 35 x 20 mm dydžio cistiniai dariniai. Kairioji kiaušidè struktūrinè. Kirmèlinèje ataugoje uždegiminių pakitimų nepastebėta. Dubens ertmejje skysčio sankaupų ar aktyvaus kontrastinès medžiagos kaupimosi nematyti. Kadangi atlikus KT tyrimą duomenų apie ūmią ginekologinę patologiją neaptikta, galvota apie funkcinị cistinị darinị kiaušidejje. Pacientei rekomenduota planinè ginekologo kontrolè po ménesinių. Paskirta Ibuprofeno $400 \mathrm{mg}$ ir ambulatoriné uždegiminių rodiklių dinamikos stebėsena šeimos gydytojo priežiūroje. Po 5 dienų, nepraejjus pilvo skausmams, moteris kreipèsi į gydytoją ginekologą ambulatorine tvarka. Vizito metu pilvas palpuojant labai skausmingas apatineje dalyje, nesant pilvaplèvès dirginimo reiškinių. Čiuopiant vaginaliai mažajame dubenyje užčiuoptas užgimdinę įdubą užpildantis skausmingas darinys. TVUG: kairiųju gimdos priedų srityje rasta $100 \times 95 \mathrm{~mm}$ dydžio darinys storomis sienelèmis su dauginèmis pertvaromis ir solidinio audinio intarpu. Atliktuose tyrimuose stebèti didejjantys kraujo uždegiminiai rodikliai: leukocitu - 14,37 x109/1, CRB 166 g/l. Tolesniam gydymui pacientė skubos tvarka siunčiama į LSMUL KK ginekologijos skyrių, kuriame stacionarizuojama. Stacionare apžiūros metu nekarščiuoja, KD 16 k/min, SpO2 99proc., hemodinamika stabili, ŠSD 100 k/min, AKS 145/85mmHg. Objektyviai: pilvas išsipūtęs, skausmingas, nesant pilvaplèvès dirginimo reiškinių. Atlikus vaginalinę apžiūrą: gimdos kaklelis aukštai, užpakalinis makšties skliautas išgaubtas, itin skausmingas. Atlikus TVUG: gimda anteversis padètyje, $125 \times 53$ x $68 \mathrm{~mm}$, endometriumas 4,9 mm, miomos mazgas užpakalinèje sienelëje 38 x 40 x $40 \mathrm{~mm}$ dydžio, pagal FIGO - 5. Stebimas cistinis, solidinis 95 x $102 \times 69$ mm dydžio darinys, esantis už gimdos, užpildantis užgimdinę įdubą ir dislokuojantis tiesiają žarną. Dešinioji kiaušidè 39 x 24 x $27 \mathrm{~mm}$ dydžio, su nedideliu vienkameriniu 21 x $20 \mathrm{~mm}$ dydžio dariniu, primenančiu cistinès kilmės folikulą. Itvertinus klinikinį vaizdą ir ligos eigą, įtartas kairiųų gimdos priklausinių apsisukimas. Nuspręsta atlikti skubią laparotomiją. Bendrinëje nejautroje Pfanenštilio pjūviu atvėrus pilvo ertmę, rasta nežymiai padidèjusi gimda, su intramuraliniu 3,5 $\mathrm{cm}$ diametro miomos mazgu užpakalinèje sienoje. Dešinieji gimdos priklausiniai be matomų pakitimų. Kairieji priklausiniai (kiaušidè su $10 \mathrm{~cm}$ cistiniu dariniu ir kiaušintakis) apsisukę apie savo išilginę ašį, edemiški bei nekrozavę. Atlikta abipusė adneksektomija ir miomektomija. Operacijos metu komplikacijų nebuvo, skirta antibiotikoprofilaktika sol. Cefazolini $2 \mathrm{~g} \mathrm{i} / \mathrm{v}$. Pacientès būklei gerèjant, po 5 dienų išrašyta iš stacionaro ị namus tęsti ambulatorinị gydymą.

\section{Diskusija}

Kiaušidès apsisukimas būdingas visų amžiaus grupių moterims, bet dažniausiai pasitaiko apie 30 gyvenimo metus $[4,5,7]$. Fiziologinès kiaušidžių cistos (funkcinè cista arba geltonkūnis) ar neoplazminiai procesai, ovuliacijos skatinimas, kiaušidžių hiperstimuliacija, policistinis kiaušidžių sindromas, kiaušintakių ligacija ir nëštumas yra laikomi kiaušidès apsisukimo rizikos veiksniais $[1,8,9]$. Apsisukimo rizika dideja, didejjant kiaušidès masei bei anamnezeje sirgusioms kiaušidès apsisukimu. Moterų, kurių anamnezèje buvo normalios kiaušidès užsisukimas, šios problemos pasikartojimo rizika 60 proc. didesnè, nei tų, kurių kiaušidè padidejjusi (8 proc.) [6]. Vis dèlto, dažniausiai pasitaikantis rizikos veiksnys yra kiaušidès dydis, didesnis nei $5 \mathrm{~cm}$. Atliktuose 3 tyrimuose, kuriuose tirta 80 ir daugiau pacienčių kiaušidžių apsisukimo problema, 86-95 proc. tiriamujjų kiaušidè buvo didesné nei $5 \mathrm{~cm}$ [1]. Esama duomenų, kad kiaušidès apsisukimas galimas ir moterims, kurių kiaušidès nepakitusios. Tokių atvejų mechanizmas neaiškus, jie dažniausi jaunoms mergaitèms, kurioms menstruacijos dar neprasidejusios $[1,3]$. Naujausių tyrimų duomenimis, šios ligos paplitimas mažesnis tarp pomenopauzinio amžiaus moterų, kadangi žemesnè kiaušidžių struktūrinių pokyčių rizika. Šioje amžiaus grupejje didesnè piktybinių kiaušidès darinių rizika [8]. Neteisingai nustatyta diagnozè ir dèl to per vèlai pradetas gydymas gali lemti kiaušidès praradimą, daryti ittaką ateities vaisingumui arba sukelti peritonitą ir mirti [6].

Remiantis moksliniu tyrimu, kuriame buvo tiriamos 380 kiaušidès apsisukimą patyrusių pacienčių, nustatyta, kad dažniausi šios patologijos simptomai buvo pilvo skausmas (97 proc.) ir teigiamas pilvaplèvès dirginimo simptomas (87,7 proc.) [8]. Nors pastarasis požymis dažnai nustatomas kiaušidès apsisukimo patologijos metu, mūsų aprašytuoju klinikiniu atveju teigiamas pilvaplèvės dirginimo simptomas nepasireiškè. Literatūroje aprašyta daugelis kitų simptomų, kurie gali padeti diagnozuojant šią patologiją. Tai pykinimas (pasitaiko $60-70$ proc. atvejų), vėmimas (45 proc.), pašonès skausmas, karščiavimas (10-20 proc.) $[6,8,10]$ ir teigiamas gimdos kaklelio simptomas (13,3 proc.) [11]. Pastarasis buvo teigiamas ir mūsų aprašytuoju atveju. Iš rečiau stebimų būklių minimas padidèjęs kraujospūdis bei širdies susitraukimų dažnis, atsiradęs dèl skausmo, apibūdinamo kaip pastovus ar praeinantis dèl to, kad kiaušidè gali apsisukti ir vèl atsisukti i pradinę padèti $[1,6]$. Atliktame tyrime, kuriame dalyvavo 44 po menopauzès ir 220 reprodukcinio amžiaus moterų su kiaušidès apsisukimu, dominuojantis simptomas buvo nepertraukiamas bukas skausmas (atitinkamai 57 proc. ir 13 proc.). Staigus ir aštrus skausmas buvo pagrindinis požymis ikimenopauzinio amžiaus moterų grupeje ( 86 proc.), o pomenopauziniu laikotarpiu šis simptomas sudare tik 43 
procentus [5]. Labai svarbi yra diferencinè klinikinès būklès diagnostika, nes panašūs skausmai gali pasireikšti ir daugelio kitų ligų metu, tokių kaip apendicitas, pielonefritas, nefrolitiazè, dubens uždegiminè liga, ektopinis nèštumas, kolitas ar plyšusios kiaušidès cistos [6]. Šie simptomai yra nespecifiniai, tad nustatyti klinikinę diagnozę sudètinga net ir naudojant šiuolaikinę vaizdo techniką, todèl teisingos priešoperacinès diagnozès atvejų skaičius yra mažas, siekiantis tik 44 procentus $[5,12,14]$.

Diagnozuojant kiaušidès apsisukimą, svarbią reikšmę turi gerai surinkta anamnezè. Pastebėta, jog jaučiami simptomai, buvę apsisukimai ir kiaušidès dariniai taip pat turi reikšmingos įtakos diagnostikai [1]. Tiriant šią ligą, būtina ịvertinti choriongonadotropiną, kuris parodo esamą nèštumą. Tai svarbu, kadangi kiaušidèje susiformavęs geltonkūnis didina apsisukimo tikimybę. Be to, žinios apie esamą néštumą padeda planuoti gydymą, išsaugant vaisių $[1,3]$. Akivaizdu, jog vaizdo tyrimai yra svarbiausi nustatyti diagnozę. Tiriant UG, apsisukusi kiaušidè gali būti apvali bei padidèjusi (dèl audinių edemos), lyginant su kontralateraline puse [3]. Doplerio ultragarsinis tyrimas kraujotakos sutrikimą nustatè 82,6 proc. iš 380 pacienčių [8]. Kito tyrimo duomenimis, doplerografijos metu sutrikusią kraujo tėkmę galima nustatyti iki 40 proc. kiaušidès apsisukimą turinčių pacienčių [6]. Kito tyrimo rezultatai parodé, kad iš 216 atvejų dopleriu tirtų pacienčių daugiau nei pusei (55 proc.) buvo registruojama sutrikusi kraujotaka [15]. Remiantis apžvalgos duomeninimis, dopleriu registruojama kiaušidès kraujotaka yra mažai jautri (43,8 proc.), bet labai specifiška ( 91,7 proc.) [11]. Mūsų aprašytu atveju diagnostikai doplerometrinis tyrimas nebuvo taikytas. Kraujotakos įvertinimui néččioms, jaunoms ir lytinių santykių neturèjusioms pacientėms dažniausiai naudojamas transabdominalinis ultragarsinis tyrimas, tačiau atliekant ultragarsinį tyrimą per pilvo sieną, kiaušidès kraujotakos vizualizacija gali būti ribota ir mažai informatyvi [6]. Teigiama, kad dubens magnetinio rezonanso tyrimas yra alternatyvus tyrimo metodas, padedantis diagnozuoti kiaušidès apsisukimą, jei ultragarsinio tyrimo duomenys kelia abejonių. Norint atmesti kitą organų patologiją, paprastai atliekama dubens organų kompiuterinè tomografija [3]. Laparoskopinė operacija turi būti apsvarstoma visoms pacientėms, ịtariant kiaušidès apsisukimą $[1,12]$. Tiksli diagnozė nustatoma tik atlikus operaciją [3]. Šios patologijos diagnostinį sudètingumą gerai atskleidè M.R. Laufer atliktas tyrimas, kuriame ištirta 115 įtariamų kiaušidès apsisukimo atvejų. Teisingas priešoperacinis diagnostinis vertinimas nustatytas tik 38 proc. tiriamujų [1].

Auksiniu kiaušidès apsisukimo gydymo standartu laikoma laparoskopinè operacija. Diagnostinè laparoskopija yra ir vienintelis diagnozès patikslinimo būdas. Operacijos metu svarbu ir onkologinis budrumas, nes ne visada prieš operaciją yra laiko ịvertinti kiaušidès darinio kilmę. Reikia įvertinti kiaušidès ir kiaušintakio gyvybingumą ir, esant galimybei, organus išsaugoti. Laiku atlikus kiaušidès atsukimo operaciją, ultragarsu atlikti stebėjimai parodè, kad kiaušidès funkcija atkuriama 80 proc. pacienčių [1,3]. Mūsų aprašytuoju atveju operacijos apimtį (abipusę adneksektomiją) nulėmè moters amžius. Laparoskopinè kiaušidès atsukimo operacija siejama su mažesniu pooperaciniu skausmu, didesniu pacienčių pasitenkinimu bei trumpesne hospitalizacija, lyginant su laparotomija. Laparoskopinè operacijos technika turètų būti pirmo pasirinkimo metodas, jei operuojamos jaunos pacientès, norinčios išsaugoti vaisingumą [8]. Apibendrinant galima teigti, kad kiaušidès apsisukimo diagnozavimas reikalauja ypatingo atidumo, siekiant išvengti galimų komplikacijų.

\section{Išvados}

1. Kiaušidès apsisukimas - tai sunkiai diagnozuojama patologija, dažniausiai pasireiškianti reprodukcinio amžiaus pacientems.

2. Pastebėjus ženkliai padidẻjusią kiaušidės apimtị ar darini joje, visuomet reikètų ịvertinti kiaušidès apsisukimo riziką ir, derinant klinikinius simptomus su vaizdiniais tyrimais, atmesti arba patvirtinti esamą patologiją.

3. Esant klinikinių simptomų ir ịtariant kiaušidès apsisukimą, būtina atlikti diagnostinę laparoskopiją.

\section{Literatūra}

1. Laufer MR. Ovarian and fallopian tube torsion. UpToDate 2020. https://www-uptodate-com.ezproxy.dbazes.lsmuni.lt/contents/ ovarian-and-fallopian-tube-torsion/print? search=adnexal torsion\&source $=$ search_result\&selectedTitle $=1 \sim 75 \&$ usage type $=$ default\&display_rank $=1$

2. Resapu P, Rao Gundabattula S, Bharathi Bayyarapu V, Pochiraju M, Surampudi K, Dasari S. Adnexal torsion in symptomatic women: a single-centre retrospective study of diagnosis and management. J Obstet Gynaecol (Lahore). 2019;39(3):349-54. https://doi.org/10.1080/01443615.2018.1494702

3. Huang C, Hong MK, Ding DC. A review of ovary torsion. Tzu Chi Med J 2017;29(3):143-7.

https://doi.org/10.4103/tcmj.tcmj_55_17

4. Robertson JJ, Long B, Koyfman A. Myths in the evaluation and management of ovarian torsion. J Emerg Med 2017;52(4):449-56. https://doi.org/10.1016/j.jemermed.2016.11.012

5. Cohen A, Solomon N, Almog B, Cohen Y, Tsafrir Z, Rimon $\mathrm{E}$, et al. Adnexal torsion in postmenopausal women: clinical presentation and risk of ovarian malignancy. J Minim Invasive Gynecol 2017;24(1):94-7.

https://doi.org/10.1016/j.jmig.2016.09.019

6. Sasaki KJ, Miller CE. Adnexal torsion: review of the literature. 
J Minim Invasive Gynecol 2014;21(2):196-202.

https://doi.org/10.1016/j.jmig.2013.09.010

7. Iraha Y, Okada M, Iraha R, Azama K, Yamashiro T, Tsubakimoto $\mathrm{M}$, et al. CT and MR imaging of gynecologic emergencies. Radiographics 2017;37(5):1569-86. https://doi.org/10.1148/rg.2017160170

8. Balci O, Energin H, Görkemli H, Acar A. Management of adnexal torsion: a 13-year experience in single tertiary center. J Laparoendosc Adv Surg Tech 2019;29(3):293-7. https://doi.org/10.1089/lap.2018.0307

9. Boswell KMO, Silverberg KM. Recurrence of ovarian torsion in a multiple pregnancy: conservative management via transabdominal ultrasound-guided ovarian cyst aspiration. Fertil Steril 2010;94(5):1910.e1-1910.e3. https://doi.org/10.1016/j.fertnstert.2010.03.020

10. Huchon C, Panel P, Kayem G, Schmitz T, Nguyen T, Fauconnier A. Does this woman have adnexal torsion? Hum Reprod 2012;27(8):2359-64. https://doi.org/10.1093/humrep/des186

11. Bar-On S, Mashiach R, Stockheim D, Soriano D, Goldenberg M, Schiff E, et al. Emergency laparoscopy for suspected ovarian torsion: are we too hasty to operate? Fertil Steril 2010;93(6):2012-5.

https://doi.org/10.1016/j.fertnstert.2008.12.022

12. Melcer Y, Maymon R, Pekar-Zlotin M, Vaknin Z, Pansky M, Smorgick N. Does she have adnexal torsion? Prediction of adnexal torsion in reproductive age women. Arch Gynecol Obstet 2018;297(3):685-90. https://doi.org/10.1007/s00404-017-4628-x

13. Huchon C, Staraci S, Fauconnier A. Adnexal torsion: a predictive score for pre-operative diagnosis. Hum Reprod 2010;25(9):2276-80.

https://doi.org/10.1093/humrep/deq173
14. Takeda A, Hayashi S, Teranishi Y, Imoto S, Nakamura H. Chronic adnexal torsion: an under-recognized disease entity. Eur J Obstet Gynecol Reprod Biol. 2017;210:45-53. https://doi.org/10.1016/j.ejogrb.2016.12.006

15. Tsafrir Z, Hasson J, Levin I, Solomon E, Lessing JB, Azem F. Adnexal torsion: cystectomy and ovarian fixation are equally important in preventing recurrence. Eur J Obstet Gynecol Reprod Biol. 2012;162(2):203-5.

https://doi.org/10.1016/j.ejogrb.2012.02.027

\section{ADNEXAL TORSION: DIAGNOSTIC CHALLENGES. A CLINICAL CASE REPORT \\ P. Burkauskas, K. Baltrušaitytė, S. Barilienė}

Keywords: ovarian torsion, adnexal torsion, abdominal pain. Summary

Adnexal torsion is a pathology in which blood flow to the ovary and / or fallopian tubes is disrupted, leading to tissue necrosis. This pathological disorder requires a special care, due to the fact that timely diagnosing the disease is not always successful, and if undiagnosed, it could be complicated by the loss of fertility, it also could induce peritonitis or even death. The accuracy of the diagnosis depends on the available resources in the hospital and gained experience of the attending physician. This article presents a clinical case in which a patient has developed ovarian torsion that could not be diagnosed immediately regarding nonspecific symptoms and the lack of information from the imaging studies, which were performed. Positive dynamics were observed after an adequate treatment of the adnexal torsion and the patient successfully went home for the further treatment.

Correspondence to: paulius.burkauskas@gmail.com

Gauta 2020-12-17 